\title{
Increased resistance to apoptosis during differentiation and syncytialization of BeWo choriocarcinoma cells
}

\author{
Bih-Rong Wei ${ }^{1,2,3}$, Chuan $\mathrm{Xu}^{1,2}$, Neal S. Rote ${ }^{1,2^{*}}$ \\ ${ }^{1}$ Department of Reproductive Biology, Case Western Reserve University School of Medicine, Case Western Reserve University, \\ Cleveland, USA \\ ${ }^{2}$ Department of Obstetrics and Gynecology, University Hospitals Case Medical Center, Cleveland, USA \\ ${ }^{3}$ SAIC-Frederick, Bethesda, USA \\ Email: weib@mail.nih.gov, *neal.rote@case.edu
}

Received 15 August 2012; revised 20 September 2012; accepted 30 September 2012

\begin{abstract}
Transition from mononuclear villous cytotrophoblast into multinuclear syncytiotrophoblast in the human placenta is accompanied by changes in apoptosisrelated proteins and an apparent increased resistance to induced apoptosis. We investigated the specific nature and timing of changes in Bcl-2, Bax, p53, and caspases 3 and 8 in forskolin-treated BeWo choriocarcinoma cells, a model for villous cytotrophoblast differentiation. BeWo cells were treated with forskolin or vehicle alone for up to $\mathbf{7 2} \mathrm{h}$ and evaluated at $\mathbf{2 4}$ $h$ intervals for syncytialization and quantitative expression specific apoptosis-related proteins and mRNAs. Syncytialization was quantified using fluorescent staining of intercellular membranes and enumeration of the percentage of nuclei in multinucleate cells, and differential localization of apoptosis-related proteins to multinuclear or mononuclear cells was determined by quantitative immunofluorescence. Forskolin treatment for up to $72 \mathrm{~h}$ resulted in $80 \%$ syncytialization, increased expression of Bcl-2 protein ( $P$ $<0.01)$ and mRNA $(P<0.05)$, and significantly decreased expression of protein and mRNA for Bax, p53, and caspases 3 and 8. Syncytialized cells expressed higher levels of Bcl-2 protein concurrent with increased resistance to cisplatin-induced apoptosis. Thus, syncytialization of BeWo cells was accompanied by altered transcription of apoptotic-related proteins characteristic of increased apoptosis resistance secondary to increased expression of the anti-apoptotic protein Bcl-2 and diminish expression of pro-apoptotic proteins.
\end{abstract}

Keywords: BeWo; Trophoblast; Placenta; Caspase 8; Caspase 3; Bcl-2; Intercellular Fusion

\footnotetext{
*Corresponding author.
}

\section{INTRODUCTION}

The surface of the human placenta is composed of multinucleate syncytiotrophoblast that expands throughout pregnancy by intercellular fusion from an underlying feeder layer of mononuclear cells (villous cytotrophoblast). Transition from mononuclear villous cytotrophoblast into multinuclear syncytiotrophoblast was accompanied by a variety of changes in the level and activity of apoptosis-related proteins [1,2]. Normal placental syncytiotrophoblast expressed antiapoptotic and proapoptotic proteins, as well as traditional indicators of apoptosis [3-8]. Some nuclei were positive for terminal deoxynucleotidyl transferase dUTP nick end labeling (TUNEL), suggesting DNA fragmentation. Areas of the syncytium contained both anti-apoptotic proteins (Bcl-2 and myeloid cell leukemia sequence 1 [Mcl-1]) and proapoptotic Bak [1,3-9]. Activated caspase 8 and Fas-associated death domain-like interleukin- $1 \beta$-converting enzyme-inhibitory protein (c-FLIP), an inhibitor of caspase 8, appeared to be expressed in villous cytotrophoblast and syncytiotrophoblast $[5,6,10]$, whereas activated caspases 3 and 8 were found only in the syncytiotrophoblast [3-5,10-12]. In spontaneously differentiating isolated term villous cytotrophoblast, however, p53, procaspase 3, and activated caspases 3 and 8 were reduced $[13,14]$. Efflux of the membrane phospholipid phosphatidylserine (PS) is a classical characteristic of apoptosis and also a necessary component of syncytiotrophoblast formation $[15,16]$.

Alterations in levels of apoptotic-related proteins may indicate decreased sensitivity to exogenous inducers of apoptosis. Although the syncytiotrophoblast in the human placenta is exposed to circulating maternal immune effector cells, the antigenically foreign fetal-placental unit appears normally resistant to immune rejection. Increased resistance to apoptosis may be one of several 
complementary survival mechanisms that protect the syncytiotrophoblast. Experiments to test whether the syncytiotrophoblast is relatively apoptosis-resistant have been equivocal. In vitro treatment of mononuclear villous cytotrophoblast and syncytiotrophoblast with staurosporine preferentially induced TUNEL-positive apoptotic nuclei in mononuclear cytotrophoblast, suggesting increased syncytiotrophoblast resistance to apoptosis [17]. In the same study, however, treatment with a combination of tumor necrosis factor-alpha (TNF- $\alpha$ ) and interferon-gamma (IFN- $\gamma$ ) induced near equal percentages of apoptotic nuclei in both cell types. Exposure of villous explant cultures to TNF- $\alpha$ or IFN- $\gamma$ resulted in a greater apoptosis in the syncytium than in villous cytotrophoblast $[18,19]$.

The concurrent change in apoptotic-related proteins and the process of differentiation and fusion of the villous cytotrophoblast into the syncytiotrophoblast suggests a role for apoptotic mechanisms in trophoblast differentiation. The potential contribution of caspase-8 to trophoblast differentiation has been discussed thoroughly in two recent reviews [20,21]. Activation of caspase-8 was proposed as an indicator of villous cytotrophoblast differentiation and intercellular fusion [22]. However, studies of placental villi and in vitro differentiation of villous cytotrophoblast have not confirmed activation of caspase-8 during differentiation [11,13,14].

To understand the role of apoptotic-related proteins in villous cytotrophoblast differentiation, the specific nature and timing of the changes must be defined. The current data are unclear because of controversial and frequently contradictory results. We hypothesized that increased resistance to apoptotic injury was an outcome of this process, and that syncytialization would be accompanied by a concurrent decrease in levels of pro-apoptotic pathway components and an increase in anti-apoptotic factors. We used BeWo cells, a controllable model of villous cytotrophoblast differentiation and syncytialization. In this study, progressive changes in expression of $\mathrm{Bcl}-2$, Bax, p53, caspases 3 and 8 mRNA and protein were correlated with formation of syncytia and increased resistance to cisplatin-induced apoptosis. Reduction in the level of caspase-3 and -8 protein levels was not accompanied by a concomitant increase in activated caspase-8, but was the apparent effect of diminished transcription.

\section{MATERIALS AND METHODS}

\subsection{Cell Culture and Fusion Induction}

BeWo, a continuous human choriocarcinoma cell line (CCL 98; ATCC, Rockville, MD), was maintained in F12K medium (Cellgro, Herndon, CA) supplemented with $10 \%$ fetal bovine serum (FBS, Invitrogen, Carlsbad,
CA, cat \# 10438-034) and a $1 \times$ mixture of penicillin G sodium, streptomycin sulfate, and L-glutamine (Invitrogen) [15]. For assays of intercellular fusion BeWo cells were transferred to MEM (Cellgro) containing the same supplements. The human choriocarcinoma lines JAR and JEG-3 were maintained in RPMI-1640 medium (Cellgro) and MEM medium, respectively, with 10\% FBS, penicillin G sodium, streptomycin sulfate, and L-glutamine.

BeWo cells undergo in vitro differentiation and intercellular fusion during treatment with $10 \mu \mathrm{M}$ of forskolin, an activator of adenylate cyclase [16]. A stock solution of $10 \mathrm{mM}$ of forskolin (Sigma-Aldrich Corp, St. Louis, MO) was prepared in dimethyl sulfoxide (DMSO, Sigma-Aldrich, cat \# P4393). Forskolin was added to each choriocarcinoma cell line to a final concentration of $10 \mu \mathrm{M}$ for up to $72 \mathrm{~h}$ with daily replacement with fresh medium and forskolin. An equal volume of DMSO was used as the vehicle control. C2C12 (ATCC, cat \# CRL1772), a murine myoblast cell line, was cultured in Dulbecco's modified Eagle's minimal essential medium with the same supplements. To induce fusion, culture medium was switched to differentiation medium in which $2 \%$ normal horse serum (Invitrogen, cat \# 16050-114) was substituted for FBS [23]. Cells were cultured in differenttiation medium for three days followed by two days in culture medium. Hematoxylin staining was performed to evaluate the degree of intercellular fusion.

\subsection{Quantifying Intercellular Fusion}

Intercellular fusion of choriocarcinoma cell lines was quantified using anti-E-cadherin staining to visualize intercellular membranes, as previously described in detail [16]. Cultures were evaluated at 24, 48, or $72 \mathrm{~h}$ after addition of forskolin. Cells grown on cover slips $\left(10^{4}\right.$ cells seeded per cover slip) in 24-well plates were fixed with $4 \%$ formaldehyde for $20 \mathrm{~min}$ followed by permeabilization with $0.5 \%$ Triton X-100 (Sigma-Aldrich, cat \# T8787) for $5 \mathrm{~min}$ at $4^{\circ} \mathrm{C}$. Cells were blocked in $2 \%$ goat serum (Sigma-Aldrich, cat \# G9023) and 2\% bovine serum albumin (BSA; Sigma-Aldrich, cat \# A7906) in phosphate-buffered saline (PBS) for $30 \mathrm{~min}$ at room temperature. Anti-E-cadherin (Table 1) was added for $1 \mathrm{~h}$ at room temperature, followed by washing and the addition of a FITC-conjugated secondary antibody for $1 \mathrm{~h}$ at room temperature. The cover slips were mounted onto slides using DAPI-containing mounting medium (Vector Laboratories, Burlingame, CA). The staining patterns were observed and recorded using a Nikon Eclipse80i microscope equipped with blue and green filters. For each cover slip, 10 fields were randomly chosen and photographed at the magnification of $200 \times$. In each field, the total numbers of DAPI stained nuclei were counted and the percentage of nuclei in multinucleate cells was determined. 
Table 1. Quantifying intercellular fusion.

\begin{tabular}{|c|c|c|c|c|c|c|c|c|}
\hline \multirow{2}{*}{ Technique } & \multicolumn{4}{|c|}{ Primary Antibodies } & \multicolumn{4}{|c|}{ Secondary Antibodies } \\
\hline & Antibody & $\begin{array}{l}\text { Antibody } \\
\text { Type }\end{array}$ & Source & $\begin{array}{l}\text { Antibody } \\
\text { Dilution }\end{array}$ & Antibody & $\begin{array}{l}\text { Antibody } \\
\text { Type }\end{array}$ & Source & $\begin{array}{c}\text { Antibody } \\
\text { Dilution }\end{array}$ \\
\hline \multirow[t]{7}{*}{ Fusion } & E-cadherin & $\begin{array}{c}\text { Mouse } \\
\text { monoclonal }\end{array}$ & $\begin{array}{c}\text { BD, cat \# } \\
610181\end{array}$ & $1: 400$ & $\begin{array}{l}\text { FITC-anti-mouse } \\
\text { IgG }\end{array}$ & $\begin{array}{c}\text { Goat } \\
\text { polyclonal }\end{array}$ & $\begin{array}{c}\text { JIR, cat \# } \\
\text { 115-095-003 }\end{array}$ & $1: 200$ \\
\hline & Bcl-2 & $\begin{array}{c}\text { Mouse } \\
\text { monoclonal }\end{array}$ & $\begin{array}{c}\text { BD, cat \# } \\
610538\end{array}$ & $0.2 \mu \mathrm{g} / \mathrm{ml}$ & & & & \\
\hline & caspase 3 & $\begin{array}{c}\text { Mouse } \\
\text { monoclonal }\end{array}$ & $\begin{array}{l}\text { BD, cat \# } \\
610323\end{array}$ & $0.2 \mu \mathrm{g} / \mathrm{ml}$ & & & & \\
\hline & caspase 8 & $\begin{array}{c}\text { Mouse } \\
\text { monoclonal }\end{array}$ & $\begin{array}{l}\text { BD, cat \# } \\
551242\end{array}$ & $0.2 \mu \mathrm{g} / \mathrm{ml}$ & & & & \\
\hline & p53 & $\begin{array}{c}\text { Mouse } \\
\text { monoclonal }\end{array}$ & $\begin{array}{l}\text { SC, cat \# } \\
\text { sc-126 }\end{array}$ & $1: 200$ & & & & \\
\hline & Bcl-xL & $\begin{array}{c}\text { Mouse } \\
\text { monoclonal }\end{array}$ & $\begin{array}{l}\text { SC, cat \# } \\
\text { sc-8392 }\end{array}$ & $1: 200$ & & & & \\
\hline & Bax & $\begin{array}{c}\text { Mouse } \\
\text { monoclonal }\end{array}$ & $\begin{array}{c}\text { SC, cat \# } \\
\text { sc-7480 }\end{array}$ & $1: 200$ & $\begin{array}{l}\text { HRP-anti-mouse } \\
\text { IgG }\end{array}$ & $\begin{array}{c}\text { Goat } \\
\text { polyclonal }\end{array}$ & $\begin{array}{c}\text { JIR, cat \# } \\
\text { 115-035-003 }\end{array}$ & $1: 5,000$ \\
\hline \multirow[t]{7}{*}{ Western blot } & $\beta$-actin & $\begin{array}{c}\text { Mouse } \\
\text { monoclonal }\end{array}$ & $\begin{array}{c}\text { SA, either cat } \\
\text { \# A1978 or } \\
\text { A2228 }\end{array}$ & $0.2 \mu \mathrm{g} / \mathrm{ml}$ & & & & \\
\hline & $\begin{array}{l}\text { mouse } \\
\text { Bcl-2 }\end{array}$ & $\begin{array}{c}\text { Mouse } \\
\text { monoclonal }\end{array}$ & $\begin{array}{l}\text { SC, cat \# } \\
\text { sc-23960 }\end{array}$ & $1: 200$ & & & & \\
\hline & $\begin{array}{c}\text { mouse } \\
\text { caspase } 3\end{array}$ & $\begin{array}{c}\text { Mouse } \\
\text { monoclonal }\end{array}$ & $\begin{array}{l}\text { BD, cat \# } \\
611048,\end{array}$ & $1: 2000$ & & & & \\
\hline & $\begin{array}{c}\text { mouse } \\
\text { caspase } 8\end{array}$ & $\begin{array}{c}\text { Mouse } \\
\text { monoclonal }\end{array}$ & $\begin{array}{l}\text { BD, cat \# } \\
551242\end{array}$ & $1: 2000$ & & & & \\
\hline & $\begin{array}{l}\text { cleaved } \\
\text { caspase } 3\end{array}$ & $\begin{array}{c}\text { Rabbit } \\
\text { monoclonal }\end{array}$ & $\begin{array}{c}\text { CST, cat \# } \\
9664\end{array}$ & $1: 1000$ & & & & \\
\hline & $\begin{array}{c}\text { cleaved } \\
\text { caspase } 8\end{array}$ & $\begin{array}{c}\text { Rabbit } \\
\text { monoclonal }\end{array}$ & $\begin{array}{c}\text { CST, cat \# } \\
9496\end{array}$ & $1: 1000$ & $\begin{array}{l}\text { HRP-anti-rabbit } \\
\text { IgG }\end{array}$ & $\begin{array}{c}\text { Goat } \\
\text { polyclonal }\end{array}$ & $\begin{array}{c}\text { JIR, cat } \\
\# 111-035-144\end{array}$ & $1: 5,000$ \\
\hline & mouse p53 & $\begin{array}{c}\text { Goat } \\
\text { polyclonal }\end{array}$ & $\begin{array}{l}\text { SC, cat \# } \\
\text { sc-1312 }\end{array}$ & $1: 200$ & $\begin{array}{l}\text { HRP-anti-goat } \\
\text { IgG, }\end{array}$ & $\begin{array}{c}\text { Rabbit } \\
\text { polyclonal }\end{array}$ & $\begin{array}{c}\text { JIR, cat } \\
\# 305-035-003\end{array}$ & ?? \\
\hline \multirow[t]{4}{*}{$\begin{array}{l}\text { Immuno- } \\
\text { fluorescence }\end{array}$} & Bcl-2 & $\begin{array}{c}\text { Rabbit } \\
\text { polyclonal }\end{array}$ & $\begin{array}{l}\text { SC, cat \# } \\
\text { sc-492 }\end{array}$ & $1: 400$ & $\begin{array}{c}\text { Texas } \\
\text { Red-anti-rabbit } \\
\text { IgG }\end{array}$ & $\begin{array}{c}\text { Donkey } \\
\text { polyclonal }\end{array}$ & $\begin{array}{l}\text { SC, cat \# } \\
\text { sc-2784 }\end{array}$ & $1: 200$ \\
\hline & caspase 3 & $\begin{array}{c}\text { Goat } \\
\text { polyclonal }\end{array}$ & $\begin{array}{l}\text { SC, cat \# } \\
\text { sc-1224 }\end{array}$ & $1: 400$ & $\begin{array}{c}\text { Texas } \\
\text { Red-anti-goat } \\
\text { IgG }\end{array}$ & $\begin{array}{c}\text { Rabbit } \\
\text { polyclonal }\end{array}$ & $\begin{array}{l}\text { SC, cat \# } \\
\text { sc-3919 }\end{array}$ & $1: 200$ \\
\hline & caspase 8 & $\begin{array}{c}\text { Rabbit } \\
\text { polyclonal }\end{array}$ & $\begin{array}{l}\text { SC, cat \# } \\
\text { sc-7890 }\end{array}$ & $1: 400$ & $\begin{array}{c}\text { Texas } \\
\text { Red-anti-rabbit } \\
\text { IgG }\end{array}$ & $\begin{array}{c}\text { Goat } \\
\text { polyclonal }\end{array}$ & $\begin{array}{l}\text { SC, cat \# } \\
\text { sc-2780 }\end{array}$ & $1: 200$ \\
\hline & p53 & $\begin{array}{c}\text { Rabbit } \\
\text { polyclonal }\end{array}$ & $\begin{array}{l}\text { SC, cat \# } \\
\text { sc-6243 }\end{array}$ & $1: 400$ & $\begin{array}{l}\text { rhodamine- } \\
\text { anti-rabbit IgG }\end{array}$ & $\begin{array}{c}\text { Goat } \\
\text { polyclonal }\end{array}$ & $\begin{array}{l}\text { SC, cat \# } \\
\text { sc-2091 }\end{array}$ & $1: 200$ \\
\hline
\end{tabular}

$B D$, BD Bioscience, San Jose, CA; CST, Cell Signaling Technology, Danvers, MA; FITC, Fluorescein isothiocyanate; HRP, horseradish peroxidase; JIR, Jackson ImmunoResearch Laboratories Inc, West Grove, PA; $M C$, monoclonal antibody; $P C$, polyclonal antibody; $S A$, Sigma-Aldrich Corp, St. Louis, MO; $S C$, Santa Cruz Biotechnology, Santa Cruz, CA. 


\subsection{Western Blot Analysis}

Cells were lysed in buffer (20 mM Tris, pH 7.4, $125 \mathrm{mM}$ $\mathrm{NaCl}, 20 \mathrm{mM} \mathrm{NaF}, 0.1 \%$ SDS, $10 \%$ glycerol, $0.5 \%$ sodium deoxylate, $1 \%$ Triton X-100, 1 mM PMSF, $2 \mu \mathrm{g} / \mathrm{ml}$ aprotinin, leupeptin, and pepstatin) and centrifuged [16]. The lysates were separated in a $4 \%-20 \%$ gradient gel (Invitrogen) and transferred onto Immobolin PVDF membranes (Millipore, Billerica, MA). The membranes were blocked in 3\% BSA and incubated with the appropriate primary antibodies and horseradish peroxidaseconjugated antibodies (see Table 1). Additional antibodies that reacted more strongly against murine Bcl-2, caspase 3 , caspase 8 , and p53 were used in Western blots of lysates from C2C12 cells. Membranes were stripped with Restore Western blot stripping buffer (Pierce, Rockford, IL) and reblotted with additional antibodies. Protein bands were quantified by densitometry of autoradiograms using a Scion Image Program (Scion Corporation, Frederick, MD). The density of each band was normalized against the paired $\beta$-actin band, and the ratio of the expression level of each target protein in forskolintreated cells to vehicle-treated cells was calculated.

\subsection{Real-Time PCR}

Total RNA was extracted from the cells using an RNeasy mini kit (Qiagen, Valencia, CA) according to the manufacturer's manual. Total cDNA was reverse transcribed using the SuperScript II First-Strand Synthesis system for RT-PCR (Invitrogen). Briefly, $5 \mu \mathrm{g}$ of total RNA was mixed with $50 \mathrm{ng}$ of random hexamers and dNTP and denatured at $65^{\circ} \mathrm{C}$ for $5 \mathrm{~min}$. A cDNA mixture containing RT buffer, $5 \mathrm{mM} \mathrm{MgCl2,} 10 \mathrm{mM}$ DTT, 2 U RNaseOUT, and $10 \mathrm{U}$ SuperScript reverse transcriptase was added to the denatured RNA. Reverse transcription was performed at $25^{\circ} \mathrm{C}$ for $10 \mathrm{~min}$ followed by $50^{\circ} \mathrm{C}$ for 50 min. RNA was digested from cDNA by adding RNaseH at $37^{\circ} \mathrm{C}$ for $20 \mathrm{~min}$. Real time PCR was carried out in a $25 \mu \mathrm{l}$ mixture of $1 \mu \mathrm{l} \mathrm{cDNA}, 2 \mu \mathrm{l} 20 \mathrm{mM}$ primer pair, $12.5 \mu$ l CYBR green PCR master mix (Applied Biosystems, Foster City, CA), and $9.5 \mu \mathrm{l}$ of water. Each reaction was performed in triplicate. Primers used in this study include: p53 (forward 5'-CCC AGC CAA AGA AGA AAC CA-3"; reverse 5'-GTT CCA AGG CCT CAT TCA GCT-3'), Bax-1 (forward 5'-CAA ACT GGT GCT CAA GGC CC-3'; reverse 5'-GCA CTC CCG CAC AAA GAT G-3'), Bcl-2 (forward 5'-CAG ATG CAC CTG ACG CCC TT-3'; reverse 5'-CCC AGC CTC CGT TAT CCT GGA-3'), Bcl-xL (forward 5'-GGG GTA AAC TGG GGT CGC ATT-3'; reverse 5'-CTT GCG AAG TTG GCG TCC A-3'), caspase 3 (forward 5'-AGA ACT GGA CTG TGG CAT TGA-3'; reverse 5'-GCT TGT CGG CAT ACT GTT TCA G-3'), caspase 8 (forward 5'AGG AGG AGA TGG AAA GGG AAC
TT-3'; reverse 5'-ACC TCA ATT CTG ATC TGC TCA CTT CT-3'), and 18S control (forward 5'-CGG CTA CCA CAT CCA AGG AA-3'; reverse 5'-GCT GGA ATT ACC GCG GCT-3'). RT-PCR was performed using a 7500 Real Time PCR System (Applied Biosystems) with a program of $95^{\circ} \mathrm{C}$ for 5 min followed by 40 cycles of $95^{\circ} \mathrm{C}$ for $15 \mathrm{~s}$ and $60^{\circ} \mathrm{C}$ for $1 \mathrm{~min}$. The 7500 System SDS software (Applied Biosystems) was used to analyze the data related to the 18S RNA control. The ratio of the mRNA level in forskolin to vehicle treated cells was calculated as $2^{\text {(CtDMSO-Ctforskolin). }}$

\subsection{Quantitative Immunofluorescence}

BeWo cells were grown and stained with anti-E-cadherin, as described above. After washing, the cells were treated for $1 \mathrm{~h}$ at room temperature with a primary antibody against an apoptosis-related protein, followed by washing and the addition of an appropriate fluorescent secondary antibody (see Table 1).

All digital images were taken using a Nikon Eclipse 80i microscope equipped with blue, green, and red filters. Fluorescent staining was quantified using MetaVue, Meta Imaging Series ${ }^{\circledR}$ 6.1(Universal Imaging Corporation, Downingtown, PA) software. Fused and non-fused cells were identified and delineated in mask images based on nuclear staining with DAPI and intercellular membrane staining with anti-E-cadherin. These delineated areas were transferred to a companion red fluorochrome image for quantitative image analysis. Each companion area was required to be in exact register with the mask image. Thresholds were set for analysis and the fluorescent density of each region quantified. Quantitative data were expressed as the ratios of fluorescent intensity between mononuclear and syncytial cells in the same culture and represent the analysis of three independent experiments. The total number (n) of measurements in those experiments ranged from 20 to 39 (mean $=28.9$, median $=29$ ).

\subsection{Apoptosis Induction}

BeWo cells were grown on cover slips in 24 well plates and treated with forskolin for $48 \mathrm{~h}$ as described above. The culture medium was removed and replaced with medium containing cisplatin (Sigma-Aldrich, cat\# P4394) at a concentration of $10 \mu \mathrm{M}$ for $16 \mathrm{~h}$. Medium was removed and cells were washed once with PBS and stained with blue-fluorescent Hoechst 33342 and green-fluorescent YO-PRO (Invitrogen). Hoechst 33342 brightly stains condensed chromatin in apoptotic cells and dimly stains the chromatin in live cells. YO-PRO can enter apoptotic cells but not the live cells. Diluted Hoechst $33342(5 \mu \mathrm{g} / \mathrm{ml})$ and YO-PRO $(0.1 \mu \mathrm{M})$ were added to the cells and incubated for $30 \mathrm{~min}$ on ice. Cells were 
washed and cover slips were mounted onto slides using VECTASHIELD mounting medium (Vector Labs). The staining patterns were recorded immediately using a Nikon Eclipse80i microscope equipped with blue and green filters and a Cool SNAP Photometrics camera.

\subsection{Statistical Analysis}

All quantitative data were expressed as mean \pm standard deviation and analyzed using one way analysis of variance/least significant difference (Tukey).

\section{RESULTS}

The BeWo model is a highly reproducible model of villous cytotrophoblast differentiation and syncytialization. Forskolin induced progressive intercellular fusion; the number of nuclei in multinucleate cells were $20.8 \% \pm$ $15.9 \%$ at $24 \mathrm{~h}(10.7 \% \pm 2.6 \%$ in the vehicle-treated control; $P=$ NS), $65.2 \% \pm 5.2 \%$ at $48 \mathrm{~h}(10.9 \% \pm 2.6 \%$ in control, $P<0.01 ; P<0.01$ compared with 24 h forskolin-treated cells), and $80.2 \% \pm 4.1 \%$ at $72 \mathrm{~h}(8.9 \% \pm$ $1.3 \%$ in control, $P<0.01 ; P<0.01$ compared with $48 \mathrm{~h}$ forskolin treated cells). These data are in very close agreement with our previous observations [16] and those of other investigators [24-27]. As we have cautioned in the past, maximum rates of intercellular fusion are not observed using media F-12, but require the use of media F-12K or MEM [28].

Bcl-2 expression was increased during forskolindriven differentiation of BeWo compared with the vehicle-treated controls (Figure 1(a)). Increased transcription preceded elevations in protein levels (Figure 1(b)); mRNA levels were increased over controls by $48 \mathrm{~h}$ (7.7 fold increase, $P<0.01$ ) and remained at a steady level through $72 \mathrm{~h}$. A resultant significant increase in protein levels occurred by $72 \mathrm{~h}$ (6.9 fold, $P<0.01)$. Expression of Bcl-xL (B-cell lymphoma-extra large), an antiapoptotic protein in the Bcl-2 protein family, was not affected by forskolin treatment of BeWo cells (data not shown).

Expression of Bax, a pro-apoptotic protein, was suppressed during differentiation of BeWo cells (Figure 1(a)). Transcription of Bax was significantly decreased by $24 \mathrm{~h}(P<0.01)$ and remained suppressed throughout all time points (Figure 1(c)). The level of protein was significantly decreased $(P<0.01)$ by $72 \mathrm{~h}$ of forskolininduced differentiation. Thus the estimated ratio of Bcl-2 to Bax was progressively increasing throughout the differentiation process; 2.2 at $24 \mathrm{~h}, 5.0$ at $48 \mathrm{~h}$, and 10.0 at $72 \mathrm{~h}$.

Treatment with forskolin also suppressed transcription of p53 mRNA (Figure 1(d)) at all time points: $39 \%$ at 24 h $(P<0.01), 56 \%$ at $48 \mathrm{~h}(P<0.01)$, and $75 \%$ at $72 \mathrm{~h}(P$ $<0.01$ ) (Figure 1(c)). Levels of p53 protein were also reduced significantly (Figure 1(d)) by 39\% at $24 \mathrm{~h}(P<$
$0.01), 52 \%$ at $48 \mathrm{~h}(P<0.01)$, and $62 \%$ at $72 \mathrm{~h}(P<$ $0.01)$.

Expression of the pro-forms of the effector caspase 3 (procaspase 3) and initiator caspase 8 (procaspase 8) were diminished during differentiation of BeWo cells (Figure 1(a)). The level of procaspase $3 \mathrm{mRNA}$ was significantly decreased by $24 \mathrm{~h}$ of treatment $(52 \%$ decrease, $P<0.01$ ), without any significant further decrease thereafter (Figure 1(e)). Protein was also significantly decreased by $24 \mathrm{~h}$ (29\% decrease, $P<0.05)$ and diminished further by $72 \mathrm{~h}$ (64\% decrease, $P<0.05$ compared to $24 \mathrm{~h}$ ). Altered expression of procaspase 8 was delayed in comparison to procaspase 3; mRNA was reduced by $42 \%$ at $48 \mathrm{~h}(P<0.01$ compared to control) with no significant further reduction thereafter, and protein was progressively reduced over the $72 \mathrm{~h}$ time span; $21 \%$ reduction at $48 \mathrm{~h}(P<0.01$ versus control, $P<0.05$ versus $24 \mathrm{~h})$ and $46 \%$ reduction at $72 \mathrm{~h}(P<0.01$ versus control, $P<0.01$ versus 24 h) (Figure 1(f)). We also measured levels of active caspases 3 and 8 to determine whether loss of procaspase proteins resulted from activetion (Figure 1(g)). No active caspase 3 bands were observed in forskolin-treated BeWo cells. Although a very small amount of activated caspase 8 was observed in BeWo treated with DMSO, the level did not significantly fluctuate during treatment with forskolin. The active fragments of both were readily observed after treating BeWo cells for $3 \mathrm{~h}$ with staurosporine, a known inducer of apoptosis (Figure 1(g)) [16].

To analyze the relationship between changes in apoptosis-related protein expression and intercellular fusion, we determined the distribution of protein between mononuclear and multinuclear cells by quantitative immunofluorescence (Figures 2(a) and (b)). Although we performed multiple time points with and without forskolin treatment $(0,24,48$, and $72 \mathrm{~h})$, only the $72 \mathrm{~h}$ samples are presented.

Bcl-2 was the only protein in our study that increased during differentiation. Microscopically, the fluorescent signal for Bcl-2 appeared more intense in syncytial cells than in mononuclear cells, which was confirmed by quantification (Figure 2(c)). Increased expression of Bcl-2 was related to syncytialization, whether spontaneous (DMSO control) or forskolin-induced; fluorescence in DMSO treated cells was more intense $(P<0.01)$ in fused cells $(90.4 \pm 12.3)$ than mononuclear cells $(77.6 \pm$ 12.0). The same relationship was observed in cells treated with forskolin: mononuclear cells, $75.2 \pm 9.6$; fused cells, $97.5 \pm 16.0(P<0.01)$. Treatment with forskolin appeared to augment the fluorescent intensity in populations of fused cells $(P=0.05)$, but not mononuclear cells $(P=\mathrm{NS})$. Increased expression of Bcl-2 protein in syncytial cells was confirmed by immunoperoxidase labeling of human placental villi, in which intense 


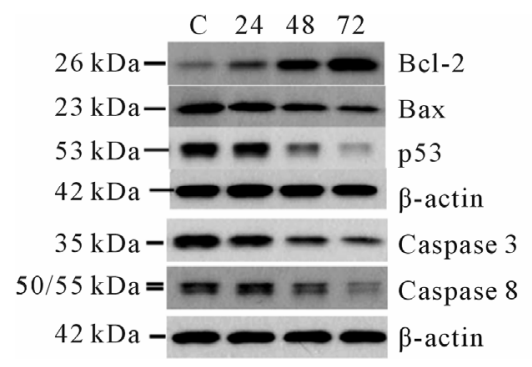

(a)

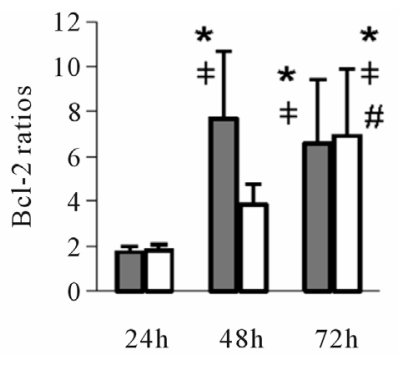

(b)

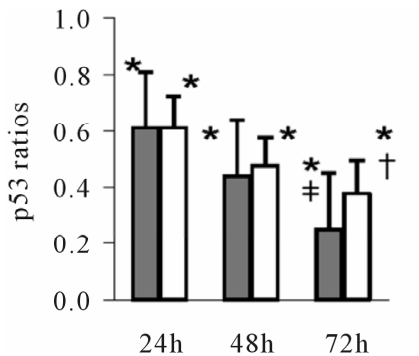

(d)

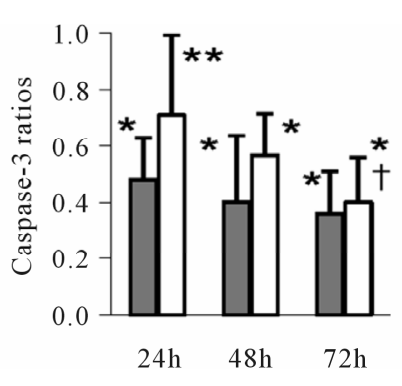

(e)

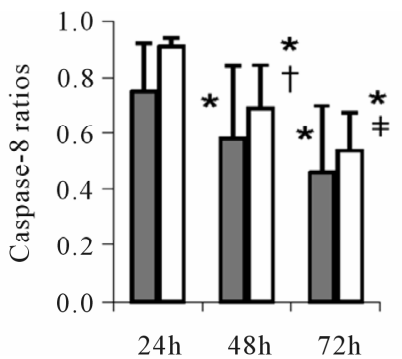

(f)

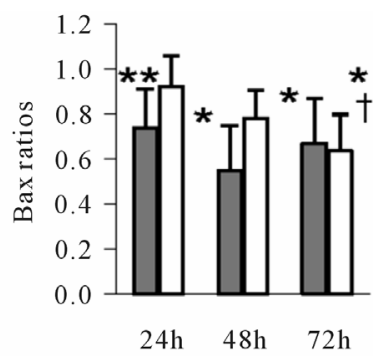

(c)

Figure 1. Expression of apoptosis-related proteins and mRNAs in BeWo cells undergoing forskolin-induced intercellular fusion. (a) Western blot analysis of extracts of BeWo cells treated with the DMSO vehicle control (Cont) for $72 \mathrm{~h}$ or forskolin for 24,48 , or 72 h; (b)-(f) Quantitative expression of Bcl-2 (b); Bax (c); p53 (d); caspase 3 (e); and caspase 8 (f) mRNA (filled bars) and protein (empty bars). Data are expressed as means and standard deviations of the ratios of forskolin-treated BeWo cells compared to the corresponding vehicle-treated controls at 24,48 , and $72 \mathrm{~h}$ of a minimum of five experiments at each time point. ${ }^{* *} P<0.01$ or ${ }^{* * * *} P<$ 0.05 relative to the matched negative control; ${ }^{\ddagger} P<0.01$ or ${ }^{\dagger} P<0.05$ relative to the $24 \mathrm{~h}$ time point; ${ }^{\#} P<0.01$ relative to the $48 \mathrm{~h}$ time point; (g) Analysis of active caspase 3 (upper blot) and active caspase 8 (lower blot) fragments (indicated by arrows) by Western blot in BeWo cells treated with vehicle control (c) or forskolin for 24,48 , or $72 \mathrm{~h}$. A positive control for caspase activation was produced by inducing apoptosis in BeWo cells using $1 \mu \mathrm{M}$ staurosporine for $3 \mathrm{~h}$ (St) [16].

staining was confined to syncytiotrophoblast (data not shown). Because of lower fluorescent intensity, relative levels of procaspase 3 , procaspase 8 , and p53 could not be accurately determined between mononuclear and syncytial cells (data not shown).

Changes in expression of apoptotic-related proteins may be unique to BeWo or secondary to intercellular fusion processes or forskolin-induced up-regulation of intracellular cAMP. We assessed the effects of forskolin on JAR and JEG-3 choriocarcinoma cells. BeWo cells readily form syncytia, whereas JAR and particularly JEG-3 cells do not routinely undergo extensive syncytialization $[29,30]$. We also evaluated a non-trophoblast model of intercellular fusion, C2C12 cells. C2C12 is a murine myoblast cell line that undergoes intercellular fusion when cultured in $2 \%$ normal horse serum instead of $10 \%$ fetal bovine serum [23]. Morphologic changes consistent with syncytialization were visible by hematoxylin staining in C2C12 cells cultured in differentiation medium compared to cells in growth medium (data not shown). Neither forskolin treatment of JAR nor JEG-3 nor intercellular fusion of $\mathrm{C} 2 \mathrm{C} 12$ cells resulted in changes in apoptotic-related proteins at 24, 48, or $72 \mathrm{~h}$ (data not shown).

Cisplatin, a drug that induces apoptotic cell death in many cell types, was added to cultures of BeWo cells treated for $48 \mathrm{~h}$ with forskolin or controls treated with vehicle alone. Cells were evaluated for apoptosis by fluorescent staining using Hoechst 33342 and YO-PRO dyes as well as Western blot analysis for activation of caspases 3 and 8 . Treatment of control cells with cisplatin resulted in apoptotic cells that stained with blue Hoechst 33342 and green YO-PRO dye (Figure 3(a)). Cells treated with forskolin displayed sparse staining (Figure 3(b)). Cisplatin induced activation of caspases 3 and 8 in control cells, but had no effect in forskolintreated cultures (Figure 3(c)). Thus, cultures of predominantly syncytialzed BeWo cells appear to be relatively resistant to the induction of apoptosis by cisplatin.

\section{DISCUSSION}

To our knowledge this is the first study to define changes in expression of apoptosis-related proteins in a controllable model of villous cytotrophoblast differentiation and intercellular fusion, BeWo cells. Syncytialization was associated with increased levels of the anti-apoptotic protein Bcl-2 and decreased expression of several proapoptotic molecules; Bax, p53, caspase 3, and caspase 8. Levels of Bcl-xL remained unchanged.

Our data are similar to previous studies of primary 


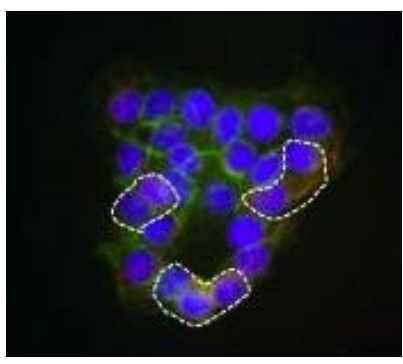

(a)

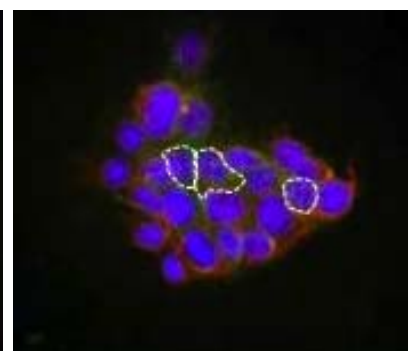

(b)

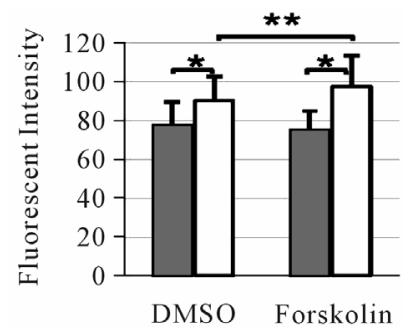

(c)

Figure 2. Quantitative immunofluorescence of Bcl-2 protein. Immunofluorescence was used to determine the distribution of Bcl-2, labeled with Texas Red-conjugated antibody, in BeWo cells treated with the DMSO vehicle alone (a) or forskolin (b) for $72 \mathrm{~h}$. Staining of cell junctions with FITC-anti-E-cadherin (green stain) was used to distinguish mononuclear from fused cells and nuclei were stained with DAPI (blue stain). In the upper photograph fused cells are circles, whereas in the lower photograph mononuclear cells are circled. (c) Fluorescent staining of Bcl-2 was quantified in mononuclear cells (filled bars) or fused cells (empty bars) and expressed as fluorescent intensity from three independent experiments. ${ }^{* *} P<0.01$ relative to indicated matched negative control, ${ }^{* * * *} P=0.05$ relative to fused cells in DMSO treated cells.

villous cytotrophoblast cultures in which levels of procaspase 3 and p53 proteins diminished between 24 and $72 \mathrm{~h}$ of culture $[13,14]$. No differences were observed in levels of procaspase 8, Bcl-2, Bax, and Bcl-xL. Although the culture conditions normally support spontaneous syncytialization of villous cytotrophoblast, markers of differentiation were not assayed. Our data confirm decreased expression of procaspase- 3 and p53 proteins extend those results; mRNA levels of each protein were also significantly reduces, suggesting an effect of differentiation at the transcriptional level. Several significant differences between studies should be noted. We observed differentiation-related increased expression of Bcl-2 protein and mRNA, with localization of the protein primarily in multinucleate cell. Our data are in agreement with reports of selectively increased expression of Bcl-2 in the syncytial layer of placenta [1,3-9]. It should be noted, however, that all in vitro models of villous cytotrophoblast differentiation, including the choriocarcinoma BeWo, primary cultures of villous cytotrophoblast, and villous explants, have inherent flaws and caveats that must be considered when interpreting data. Although

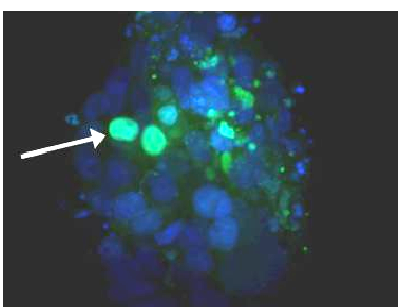

(a)

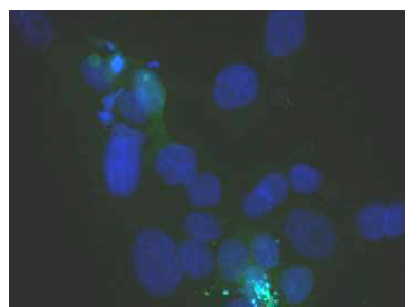

(b)

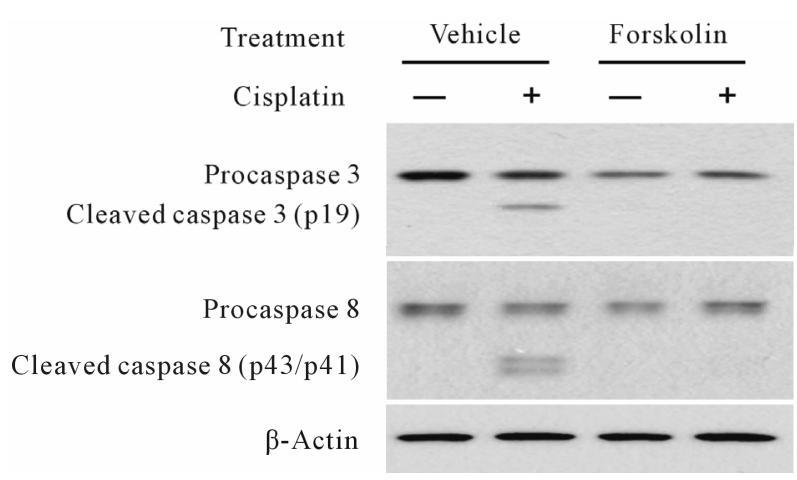

(c)
Figure 3. Cisplatin treatment of BeWo cells. BeWo cells were treated with either vehicle alone (a) or forskolin (b) for $48 \mathrm{~h}$ followed by $10 \mu \mathrm{M}$ cisplatin for $16 \mathrm{~h}$. YO-PRO and Hoechst 33342 were used to assess apoptosis (green apoptotic cells are indicated by the arrow in (a)). (c) Western blot analysis of cisplatin-induced (lanes with + ) activation of caspase 8 in BeWo cell cultures pretreated with vehicle alone or forskolin.

BeWo is a choriocarcinoma, the characteristics of forskolin-induced syncytialization appear to closely replicate those seen in situ.

Decreased procaspase levels may result from diminished expression or increased consumption, one method of which is caspase activation. Using isolated placental villi, activation of caspase 8 was observed in mononuclear villous cytotrophoblast preceded syncytialization, whereas activation of caspase 3 was only observed in syncytiotrophoblast [4]. However in primary villous cytotrophoblast cultures, both activated caspases 3 and 8 were observed at $24 \mathrm{~h}$ of culture, and their levels decreased over the next $48 \mathrm{~h}$, during the period in which syncytialization would be occurring [13]. We observed no evidence of caspase 3 or 8 activation and diminished caspase expression appeared to reflect down-regulation of transcription preceding syncytialization.

Diminished expression of pro-apoptotic proteins and increased Bcl-2 expression during transition of the villous cytotrophoblast to the syncytial phenotype may indicate a decreased sensitivity to induction of apoptosis. The syncytiotrophoblast has developed multiple active and passive mechanisms for preventing recognition and attack by the maternal immune and inflammatory systems [31]. The trophoblast may actively thwart potentially damaging maternal effector cells through expres- 
sion of Fas ligand (FasL) on the cell surface and secretion of soluble apoptosis-inducing FasL into the maternal circulation [32]. The syncytiotrophoblast also expresses high levels of four different receptors for TNF-related apoptosis-inducing ligand (TRAIL) [33]. Macrophages are susceptible to apoptosis induced by TRAIL, thus over-expression of TRAIL may be an active mechanism that is important for maintaining the immune privilege status of the placenta.

Members of the Bcl-2 family are divided into two sub groups according to their roles in apoptosis; anti-apoptotic proteins (e.g. Bcl-2 and Bcl-xL) and pro-apoptotic proteins (e.g., Bax, Bad [Bclantagonist of cell death], Bid). The anti-apoptotic activity of Bcl-2 is often dependent on its relative concentration to Bax, so that an increasing $\mathrm{Bcl}-2 / \mathrm{Bax}$ ratio is indicative of resistance to apoptosis [34,35]. In other cell models over- expression of Bcl-2 inhibited Bax-induced activation of caspase 3 and rescued cells from apoptosis [36]. Syncytialized BeWo cells expressed increased levels of Bcl-2 and reduced protein level of Bax resulting in an increased $\mathrm{Bcl}-2 / \mathrm{Bax}$ ratio. Indeed, syncytialized BeWo cells were more resistant to cisplatin-induced apoptosis than were mononuclear BeWo cells.

Changing levels of Bcl-2 and Bax protein appeared to reflect altered transcription. Transcription of Bcl-2 and Bax are regulated by $\mathrm{p} 53$, which generally suppresses the expression of anti-apoptotic proteins and stimulates expression of pro-apoptotic molecules, such as Bax [37]. Decreased expression of p53 during BeWo cell syncytialization precedes significant changes in Bcl-2 expression, which may indicate a causal interrelationship.

Increased resistance to apoptosis appears to specifically relate to trophoblast syncytialization, rather than be a general phenomenon of intercellular fusion. Under normal physiologic conditions very few cells undergo intercellular fusion; one of which is the skeletal myoblast that fuses to form multinuclear myotubes. Fusion of a myoblast model, C2C12 cells, was not accompanied by alterations in expression of apoptosis-related proteins. Induced resistance to apoptosis is more critical for the syncytiotrophoblast, which is derived from immunologically foreign fetal tissue and a more likely target for maternal immune cells.

\section{ACKNOWLEDGEMENTS}

The authors thank Liping Luo for her skillful technical assistance in portions of this study. This work was supported in part by grants RO1HD043566 and R21-HD052803 from the National Institutes of Health to NSR.

\section{REFERENCES}

[1] Straszewski-Chavez, S.L., Abrahams, V.M. and Mor, G.
(2005) The role of apoptosis in the regulation of trophoblast survival and differentiation during pregnancy. Endocrine Reviews, 26, 877-897. doi:10.1210/er.2005-0003

[2] Heazell, A.E.P. and Crocker, I.P. (2008) Live and let die-Regulation of villous trophoblast apoptosis in normal and abnormal pregnancies. Placenta, 29, 772-783. doi:10.1016/j.placenta.2008.07.003

[3] Huppertz, B., Frank, H.G., Kingdom, J.C., Reister, F. and Kaufmann, P. (1998) Villous cytotrophoblast regulation of the syncytial apoptotic cascade in the human placenta. Histochemistry and Cell Biology, 110, 495-508. doi:10.1007/s004180050311

[4] Huppertz, B., Frank, H.G., Reister, F., Kingdom, J., Korr, H. and Kaufmann, P. (1999) Apoptosis cascade progresses during turnover of human trophoblast: Analysis of villous cytotrophoblast and syncytial fragments in vitro. Laboratory Investigation, 79, 1687-1702.

[5] Ratts, V.S., Tao, X.J., Webster, C.B., et al. (2000) Expression of BCL-2, BAX and BAK in the trophoblast layer of the term human placenta: A unique model of apoptosis within a syncytium. Placenta, 21, 361-366. doi:10.1053/plac.1999.0486

[6] Huppertz, B., Tews, D.S. and Kaufmann, P. (2001) Apoptosis and syncytial fusion in human placental trophoblast and skeletal muscle. International Review of Cytology, 205, 215-253. doi:10.1016/S0074-7696(01)05005-7

[7] Danihel, L., Gomolcak, P., Korbel, M., et al. (2002) Expression of proliferation and apoptotic markers in human placenta during pregnancy. Acta Histochemica, 104, 335338. doi:10.1078/0065-1281-00683

[8] Ishihara, N., Matsuo, H., Murakoshi, H., Laoag-Fernandez, J.B., Samoto, T. and Maruo, T. (2002) Increased apoptosis in the syncytiotrophoblast in human term placentas complicated by either preeclampsia or intrauterine growth retardation. American Journal of Obstetrics and Gynecology, 186, 158-166.

doi:10.1067/mob.2002.119176

[9] Ishihara, N., Matsuo, H., Murakoshi, H., Laoag-Fernandez, J., Samoto, T. and Maruo, T. (2000) Changes in proliferative potential, apoptosis and $\mathrm{Bcl}-2$ protein expression in cytotrophoblasts and syncytiotrophoblast in human placenta over the course of pregnancy. Endocrine Journal, 47, 317-327. doi:10.1507/endocrj.47.317

[10] Ka, H. and Hunt, J.S. (2003) Temporal and spatial patterns of expression of inhibitors of apoptosis in human placentas. American Journal of Pathology, 163, 413-422. doi:10.1016/S0002-9440(10)63671-1

[11] Black, S., Kadyrov, M., Kaufmann, P., Ugele, B., Emans, N. and Huppertz, B. (2004) Syncytial fusion of human trophoblast depends on caspase 8. Cell Death and Differentiation, 11, 90-98. doi:10.1038/sj.cdd.4401307

[12] Huppertz, B., Frank, H.G. and Kaufmann, P. (1999) The apoptosis cascade-morphological and immunohisto-chemical methods for its visualization. Anatomy and Embryology, 200, 1-18. doi:10.1007/s004290050254

[13] Yusuf, K., Smith, S.D., Sadovsky, Y. and Nelson, D.M. 
(2002) Trophoblast differentiation modulates the activity of caspases in primary cultures of term human trophoblasts. Pediatric Research, 52, 411-415. doi:10.1203/00006450-200209000-00018

[14] Hu, C., Smith, S.D., Pang, L., Sadovsky, Y. and Nelson, D.M. (2006) Enhanced basal apoptosis in cultured term human cytotrophoblasts is associated with a higher expression and physical interaction of p53 and Bak. Placenta, 27, 978-983. doi:10.1016/j.placenta.2005.11.004

[15] Rote, N.S., Chang, J., Katsuragawa, H., Ng, A.K., Lyden, T.W. and Mori, T. (1995) Expression of phosphatidylserine-dependent antigens on the surface of differentiating BeWo human choriocarcinoma cells. American Journal of Reproductive Immunology, 33, 114-121.

[16] Das, M., Xu, B., Lin, L., Chakrabarti, S., Shivaswamy, V. and Rote, N.S. (2004) Phosphatidylserine efflux and intercellular fusion in a BeWo model of human villous cytotrophoblast. Placenta, 25, 396-407. doi:10.1016/j.placenta.2003.11.004

[17] Crocker, I.P., Barratt, S., Kaur, M. and Baker, P.N. (2001) The in vitro characterization of induced apoptosis in placental cytotrophoblasts and syncytiotrophoblasts. Placenta, 22, 822-830. doi:10.1053/plac.2001.0733

[18] Crocker, I.P., Tansinda, D.M., Jones, C.J.P. and Baker, P.N. (2004) The influence of oxygen and tumor necrosis factor- $\alpha$ on the cellular kinetics of term placental villous explants in culture. Journal of Histochemistry \& Cytochemistry, 52, 749-757. doi:10.1369/jhc.3A6176.2004

[19] Balkundi, D.R., Ziegler, J.A., Watchko, J.F., Craven, C. and Trucco, M. (2003) Regulation of FasL/Fas in human trophoblasts: Possible implications for chorioamniotis. Biology of Reproduction, 69, 718-724. doi:10.1095/biolreprod.102.013102

[20] Gauster, M. and Huppertz, B. (2010) The paradox of caspase 8 in human trophoblast fusion. Placenta 31, 82-88. doi:10.1016/j.placenta.2009.12.007

[21] Rote, N.S., Wei, B-R., Xu, C. and Luo, L. (2010) Caspase 8 and human villous cytotrophoblast differentiation. Placenta, 31, 89-96. doi:10.1016/j.placenta.2009.12.014

[22] Gauster, M., Siwetz, M. and Huppertz, B. (2009) Fusion of villous trophoblast can be visualized by localizing active caspase 8. Placenta, 30, 547-550. doi:10.1016/j.placenta.2009.03.007

[23] Fernando, P., Kelly, J.F., Balazsi, K., Slack, R.S. and Megeney, L.A. (2002) Caspase 3 activity is required for skeletal muscle differentiation. Proceedings of the $\mathrm{Na}$ tional Academy of Sciences, 99, 11025-11030. doi:10.1073/pnas.162172899

[24] Wice, B., Menton, D., Geuze, H. and Schwartz, A.L.
(1990) Modulators of cyclic AMP metabolism induce syncytiotrophoblast formation in vitro. Experimental Cell Research, 186, 306-316. doi:10.1016/0014-4827(90)90310-7

[25] Mi, S., Lee, X., Li, X.-P., et al. (2000) Syncytin is a captive retroviral envelope protein involved in human placental morphogenesis. Nature, 403, 785-789. doi: $10.1038 / 35001608$

[26] Hu, R., Jin, H., Zhou, S., Yang, P. and Li, X. (2007) Proteomic analysis of hypoxia-induced responses in the syncytialization of human placental cell line BeWo. Placenta, 28, 399-407. doi:10.1016/j.placenta.2006.07.005

[27] Rashid-Doubell, F., Tannetta, D., Redman, C.W.G., Sargent, I.L., Boyd, C.A.R. and Linton, E.A. (2007) Caveolin-1 and lipid rafts in confluent BeWo trophoblasts: Evidence for Rock-1 association with caveolin-1. Placenta, 28, 139-151. doi:10.1016/j.placenta.2005.12.005

[28] Rote, N.S. (2005) Intercellular fusion of BeWo. Placenta, 26, 686. doi:10.1016/j.placenta.2004.09.003

[29] Borges, M., Bose, P., Frank, H.G., Kaufmann, P. and Potgens, A.J. (2003) A two-colour fluorescence assay for the measurement of syncytial fusion between trophoblastderived cell lines. Placenta, 24, 959-964. doi:10.1016/S0143-4004(03)00173-5

[30] Al-Nasiry, S., Spitz, B., Hanssens, M., Luyten, C. and Pijnenborg, R. (2006) Differential effects of inducers of syncytialization and apoptosis on BeWo and JEG-3 choriocarcinoma cells. Human Reproduction, 21, 193201. doi:10.1093/humrep/dei272

[31] Jerzak, M. and Bischof, P. (2002) Apoptosis in the first trimester human placenta: the role in maintaining immune privilege at the maternal-foetal interface and in the trophoblast remodelling. European Journal of Obstetrics \& Gynecology and Reproductive Biology, 100, 138-142. doi:10.1016/S0301-2115(01)00431-6

[32] Abrahams, V.M., Straszewski-Chavez, S.L., Guller, S. and Mor, G. (2004) First trimester trophoblast cells secrete Fas ligand which induces immune cell apoptosis. Molecular Human Reproduction, 10, 55-63. doi:10.1093/molehr/gah006

[33] Phillips, T.A., Ni, J., Pan, G., et al. (1999) TRAIL (Apo-2L) and TRAIL receptors in human placentas: Implications for immune privilege. Journal of Immunology, 162, 6053-6059.

[34] Stoetzer, O.J., Nüssler, V., Darsow, M., et al. (1996) Association of bcl-2, bax, bcl-xL and interleukin-1 betaconverting enzyme expression with initial response to chemotherapy in acute myeloid leukemia. Leukemia, 10, S18-S22. 